\title{
9.5 Типологія шахрайства у банківській сфері: сутність, умови виникнення та розробка заходів боротьби
}

Забезпечення фінансової безпеки банківської установи $є$ актуальною проблемою сьогодення і має здійснюватися на основі розробленої стратегії. Адже низка численних загроз фінансовій безпеці банку як зовнішніх, так i внутрішніх посилює потребу у розробленні комплексного підходу до їх виявлення, аналізу та системної розробки заходів щодо їх запобігання. Тому, погоджуємося з автором [478], що першочерговим завданням є запровадження принципів Базель III, які базуються на принципах управління капіталом та його ліквідністю з метою підвищення стійкості банківського сектору, забезпечення стабільної бази та необхідних резервів з метою протистояти ризикам та кризам. Звідси, фінансова стратегія забезпечення фінансової безпеки банку - це комплекс заходів, які спрямовані на збільшення його вартості, забезпечення платоспроможності, ліквідності та стійкості, ефективної структури капіталу, найбільш прибуткових його вкладень та своєчасне виявлення $\mathrm{i}$ усунення можливих загроз. Метою стратегії $є$ збільшення вартості банку, його прибутковості та розширення позицій на ринку банківських послуг.

Стратегія забезпечення фінансової безпеки банку розробляється відповідно до нормативів НБУ та має узгоджуватися із загально стратегією і розроблятися на основі чинної нормативно-законодавчої бази [478].

Перш за все розглянемо сутність шахрайства 3 правової точки зору, яке згідно ст. 190 Кримінального кодексу України означає «заволодіння чужим майном або придбання права на майно шляхом обману чи зловживанням довірою» [479]. Шахрайство завжди містить прямий умисел на вчинення 
шахрайських дій та корисливі мотиви заподіяння. Крім ст.190 прописано відповідальність за шахрайство, як спосіб вчинення інших злочинів (рис. 9.5.1).

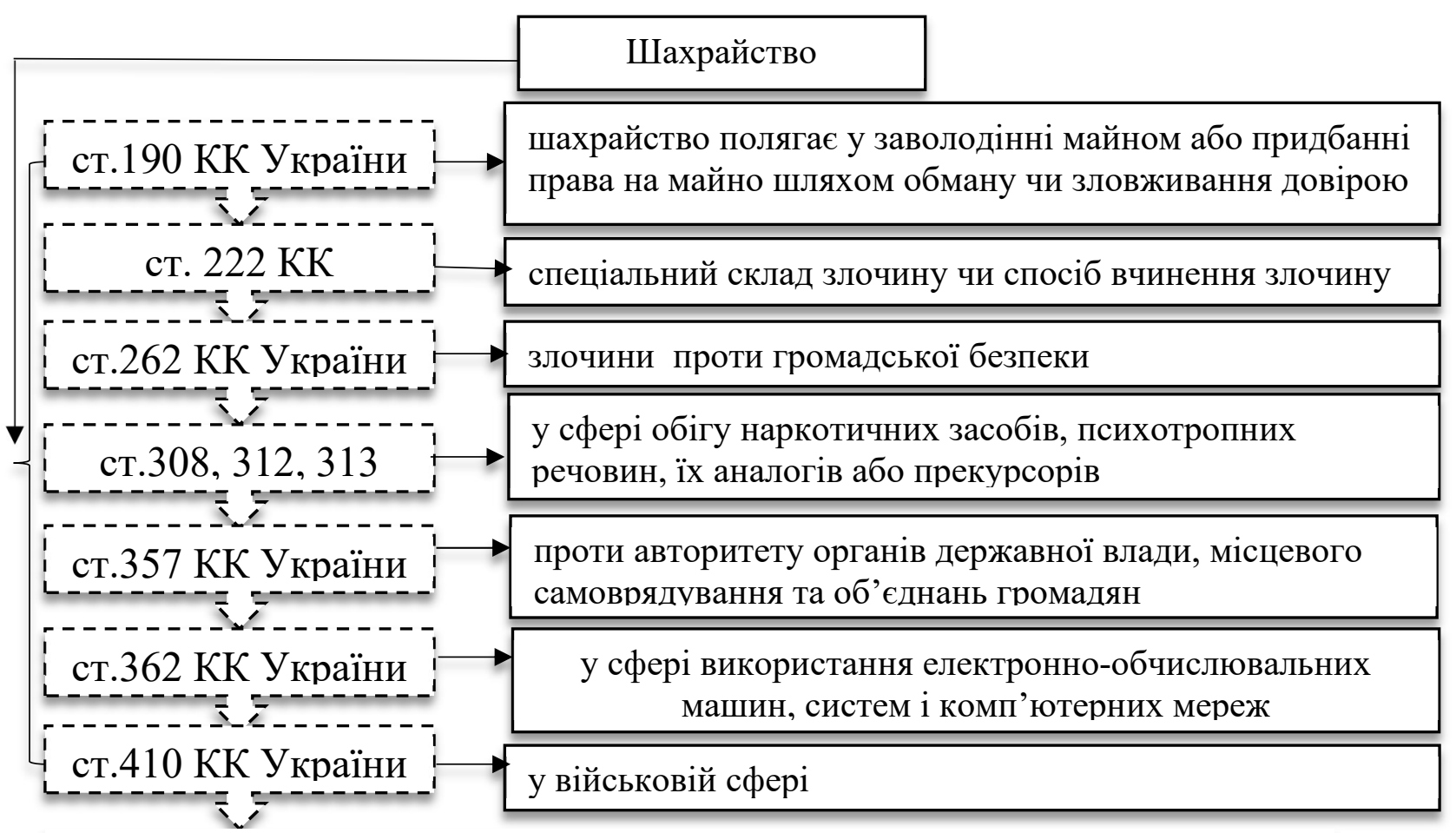

Рис. 9.5.1. Відповідальність за шахрайство

Якщо брати в загальному, то банківська система є однією з основних ланок фінансово-кредитної системи України і є об’єктом, яка приваблює шахраїв та злочинців, використовується платформою для відмивання коштів. Ці факти підривають авторитет банків, як фінансових посередників, що гарантують збереження та накопичення коштів клієнтів: населення, держави та суб’єктів господарювання.

У сучасному світі види та способи вчинення шахрайств змінюються. 3 розвитком новітніх технологій питання шахрайства особливо актуалізувалися. Сьогодні шахрайство проявляється у всіх сферах діяльності, проникає в різні організації та установи, однак особливо вразливою сферою виявився банківський сектор.

Автори [478] зазначають, що шахрайство у комерційному банку $\epsilon$ «сукупністю злочинних дій та маніпуляцій 3 метою заволодіння коштами комерційного банку або його клієнтів»; «Банківське шахрайство - це не 
ситуативний акт, а ретельно спланована та організована діяльність 3 чіткою метою отримати матеріальну вигоду. Фінансове шахрайство характеризується визначенням мети, повторенням дій, послідовністю здійснення та відтермінування прояву тощо» [478, с.104]. При цьому потрібно зазначити, що особливістю шахрайства є те, що власник чи особа, яка зберігає майно, кошти, цінності, добровільно передає їх зловмиснику, не усвідомлюючи наявного обману чи зловживання довірою. Найбільш актуальними, на нашу думку, є такі види шахрайства: зловживання вчинені 3 порушенням кредитування та банківських розрахунків (Г.Матусовський, О.Бушан); розкрадання, хабарі, інші суспільно-небезпечні посилання (В.Попович); поширення інформаційних технологій у банківській сфері (спрощення банківських операцій, поширення шахрайських дій), впровадження банківських карт; фальсифікація документів, використання фіктивних підприємств (О.Кришевич).

Загалом, сьогодні Україна стала плацдармом для вчинення різного виду шахрайств. Тому перш ніж працювати чи підписувати якісь документи потрібно чітко визначити з ким ми працюємо. Для цього потрібно отримати інформацію: про наявність ліцензій займатися певною діяльністю; про розміщення та офіси майбутніх партнерів чи посередників; повну інформацію про власника чи бенефіціара. Другим важливим моментом є те, що потрібно дізнатися - а що саме пропонують нам претенденти на співпрацю, а саме: які пропонуються відсотки та які надаються гарантії; чи виставляються додаткові умови по передоплаті або окремої плати за прискорення процедури вирішення питання; якщо пропонуються інвестиції в проєкти, то чи офіційно зареєстровані останні; чи не створюється фінансова піраміда; чи не поступають пропозиції залучати друзів та родичів тощо.

Стосовно специфіки банківського шахрайства погоджуємося з науковцями, що банк може виступати як жертвою в руках шахраїв, так і інструментом його вчинення [480, с.114]. Як жертвою банк може виступати, коли надаються кредити особам, які заздалегідь планують не віддавати їх; кредити по підроблених документах тощо. Однак це якщо працівники добросовісно 
перевірили позичальника і не виявили ознак підробки чи недоброчесності. Але наявними $є$ факти, коли недобросовісні працівники банку по домовленості 3 третіми особами за певну винагороду приймають сфальсифіковані документи і видають кредити, наносячи збитки банку. Крім того банки можуть слугувати інструментом «липових» переказів на рахунок фірми-постачальника до відвантаження товару (знову ж таки по домовленості осіб), а потім відкликання коштів, як помилково переведених; може банк співпрацювати з групами осіб, компаніями чи фірмами, які займаються відмиванням коштів.

Таким чином можна виокремити зовнішне та внутрішне шахрайство. Зовнішнє шахрайство за даними дослідження KPMG, «у 2018 році 61\% респондентів повідомили про зростання загальної кількості випадків зовнішнього шахрайства, а 59\% заявили про збільшення сум шахрайських операцій. У більшості випадків респонденти вважали, що середня сума кожної шахрайської операції не змінилася (21\%) або зменшилася (38\%). Це можна пояснити великою кількістю шахрайських операцій з картками, сума яких була незначною» [481].

Як зазначено у вищезгаданому дослідженні нова типологія шахрайських операцій (2015-2018рр.), містить як основу «крадіжку персональних даних та використання номера картки для шахрайства / шахрайство від імені принципала, кібератаки, шахрайство з безкартковими операціями та протиправні схеми» [481]. За результатами цього ж дослідження небезпечним для суб'єкта $\epsilon$ внутрішне шахрайство (з боку його працівників). Так, найбільша частка опитаних заявили, що загальна вартість, середня вартість та кількість випадків внутрішнього шахрайства у 2017 і 2018 роках лишилися незмінними або скоротилися. Однак ця інформація може не відображати повну картину впливу внутрішнього шахрайства на фінансову установу, оскільки велика кількість зовнішніх атак є результатом співпраці досвідчених злочинців 3 внутрішніми джерелами, які детально знають банківські системи, процеси та засоби контролю (а також недоліки та слабкі місця систем контролю). Потенційна шкода від шахрайства з боку інсайдерів може бути не меншою, якщо не більшою, за шкоду 
від зовнішнього шахрайства, враховуючи спроможність працівників використовувати слабкі місця засобів контролю з метою привласнення найбільш цінних активів банку. Банкам краще й надалі діяти на випередження 3 метою виявлення шахрайства з боку інсайдерів.

Можна виділити наступні способи шахрайства (рис. 9.5.2):

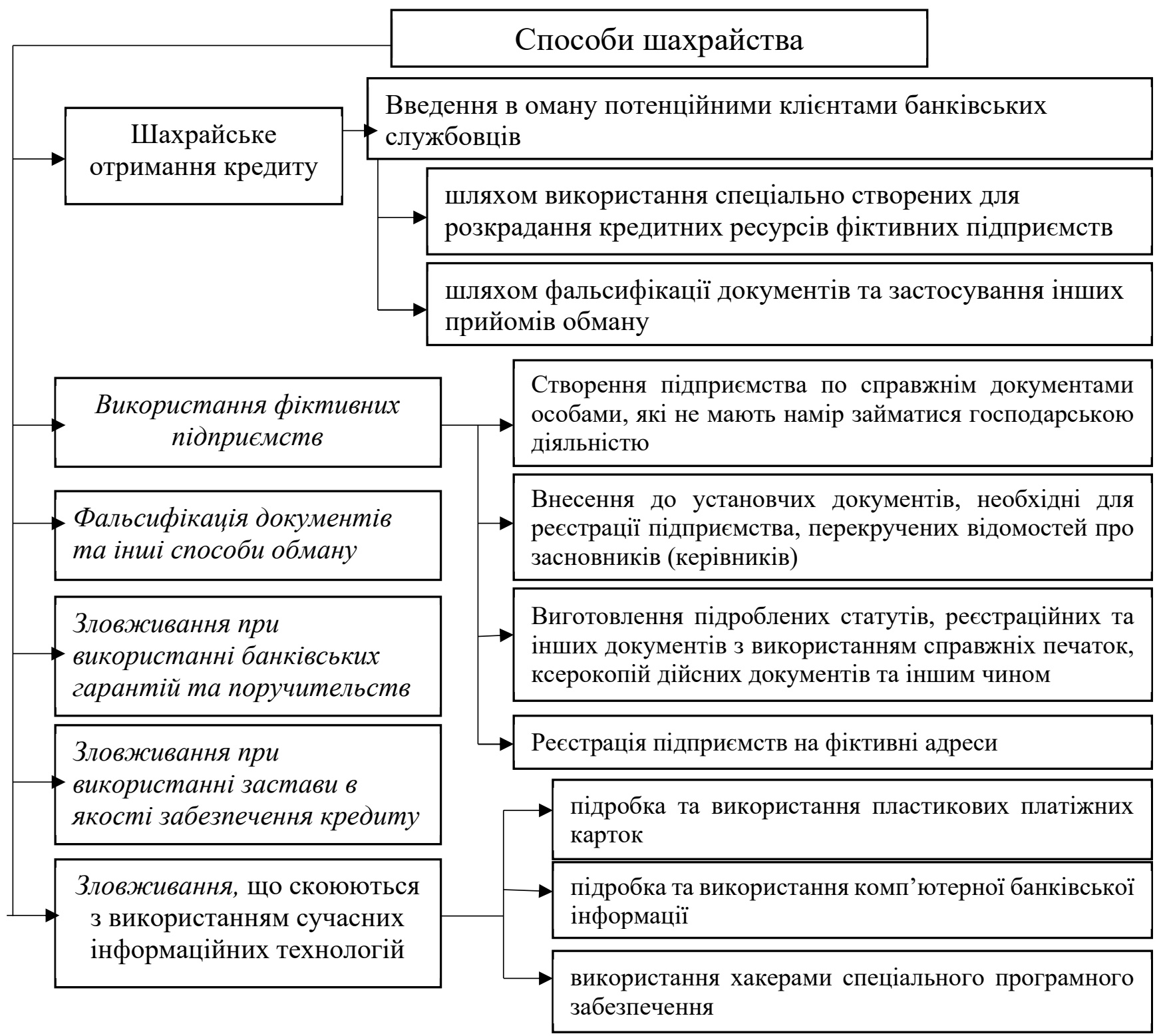

Рис. 9.5.2. Способи шахрайства

О.В. Кришевич виділяє основні чотири способи комп’ютерного шахрайства, a came:

(1) безпосереднє та електромагнітне перехоплення інформації; 
(2) крадіжки програмного забезпечення, крадіжки устаткування, неправомірне отримання кодів;

(3) маніпуляції з інформацією;

(4) несанкціонований доступ до інформації [480, С.591].

Зазвичай, кожна злочинна дія розпочинається 3 отримання контактної інформації, доступу зловмисників до ЕОМ, скачування інформації, зняття коштів та акумулювання їх на «липових рахунках фірм-одноденок» тощо. Такі злочини приховуються через відновлення програмного забезпечення і тому складні у виявленні.

В період 2016-2018 рр. ми спостерігаємо тенденцію зменшення кількості кримінальних злочинів загалом та економічних злочинів, зокрема. Так, експерти зазначають, що спад кількості зареєстрованих злочинів є свідченням зниження активності правоохоронців у цій сфері, а не прямого зменшення даного виду злочинності (рис. 9.5.3).

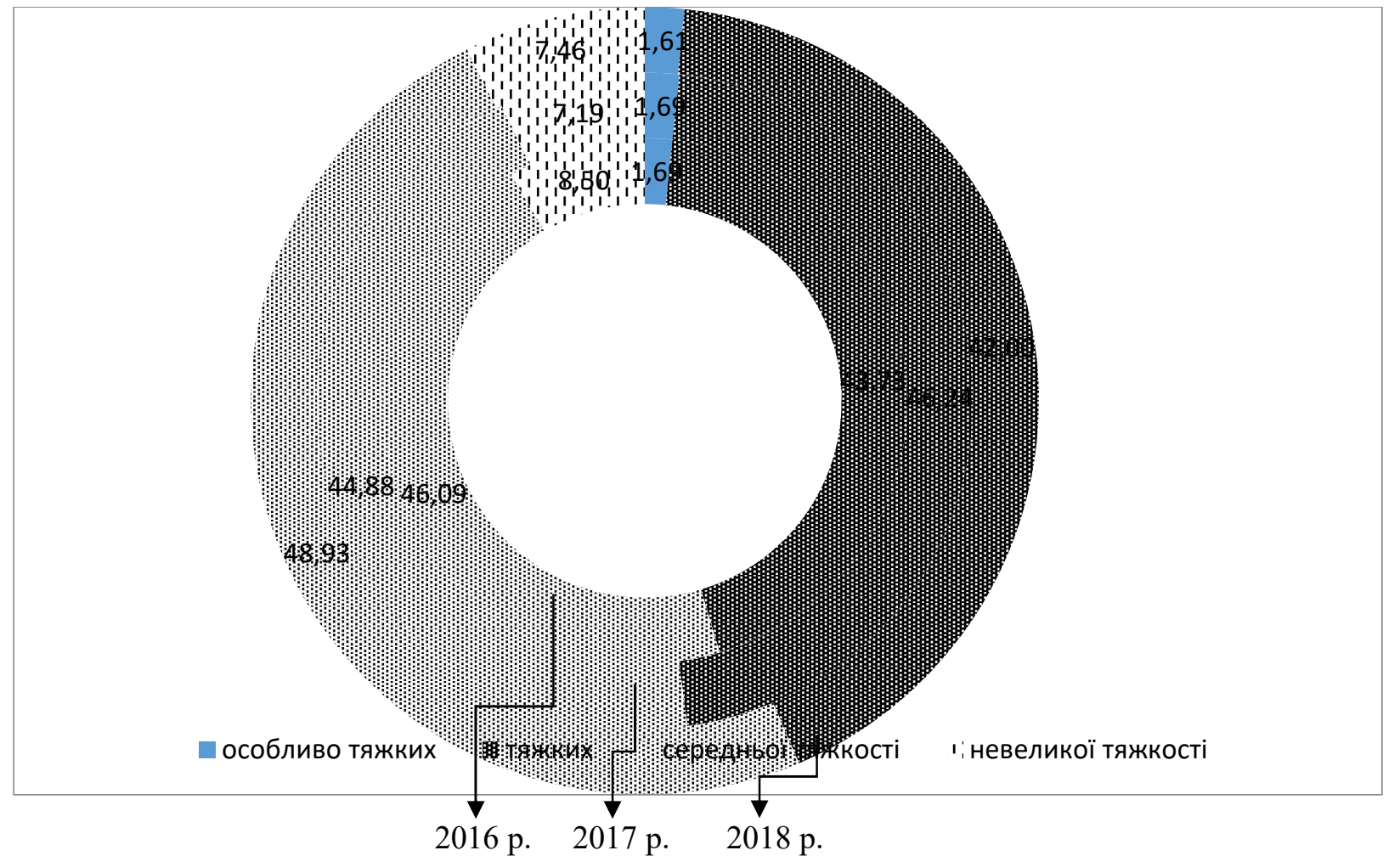

Рис. 9.5.3. Структура злочинів проти власності в Україні за 2016-2018 pp., \% від загальної кількості Складено за даними [482] 
Найбільшу частку в кримінальних злочинах займають злочини проти власності. Водночас, у загальній кількості злочинів найбільшу питома вагу займають тяжкі злочини та злочини середньої тяжкості (табл. 9.5.1).

Таблиця 9.5.1

Динаміка злочинів проти власності в Україні за 2016-2018 pp.

\begin{tabular}{|l|c|c|c|c|}
\hline \multicolumn{1}{|c|}{ Види злочинів } & $2016 \mathrm{p}$. & $2017 \mathrm{p}$. & $2018 \mathrm{p}$. & $\begin{array}{c}\text { Абсолютне } \\
\text { відхилення 2018 } \\
\text { до } 2016 \mathrm{p} .\end{array}$ \\
\hline Злочини проти власності & 405549 & 335910 & 303850 & -101699 \\
\hline Крадіжка & 312172 & 261282 & 238492 & -73680 \\
\hline Грабіж & 27199 & 18130 & 13838 & -13361 \\
\hline Розбій & 3904 & 3006 & 2263 & -1641 \\
\hline Шахрайство & 46019 & 37014 & 33290 & -12729 \\
\hline $\begin{array}{l}\text { Привласнення, розтрата майна або } \\
\text { заволодіння ним шляхом } \\
\text { зловживання службовим становищем }\end{array}$ & 9787 & 10756 & 10713 & 926 \\
\hline $\begin{array}{l}\text { Умисне знищення або пошкодження } \\
\text { майна }\end{array}$ & 3105 & 2714 & 2551 & -554 \\
\hline Інші & 190418 & 191009 & 2703 & -187715 \\
\hline
\end{tabular}

Складено за даними Генеральної прокуратури України [482]

3 табл. 1 видно, що упродовж періоду, що аналізується кількість злочинів проти власності скоротилася на 101699 злочинів. Найбільше упродовж аналізованого періоду здійснювалось крадіжок, шахрайських дій та грабежів.

За результатами дослідження, проведеного компанією $\mathrm{PwC}$, у 2018 році 48\% вітчизняних юридичних осіб постраждали від економічних злочинів та шахрайств, що на 5 \% більше, аніж у 2016 р. [483]. Опитані респонденти зазначили, що найбільш часто вони дотичні із з фактами вимагання, хабарництва i корупції (73\%). Значну частку займають такі злочини, як: незаконне привласнення майна, злочини у сфері публічних закупівель, шахрайство при управління персоналом та кіберзлочини (рис. 9.5.4). 


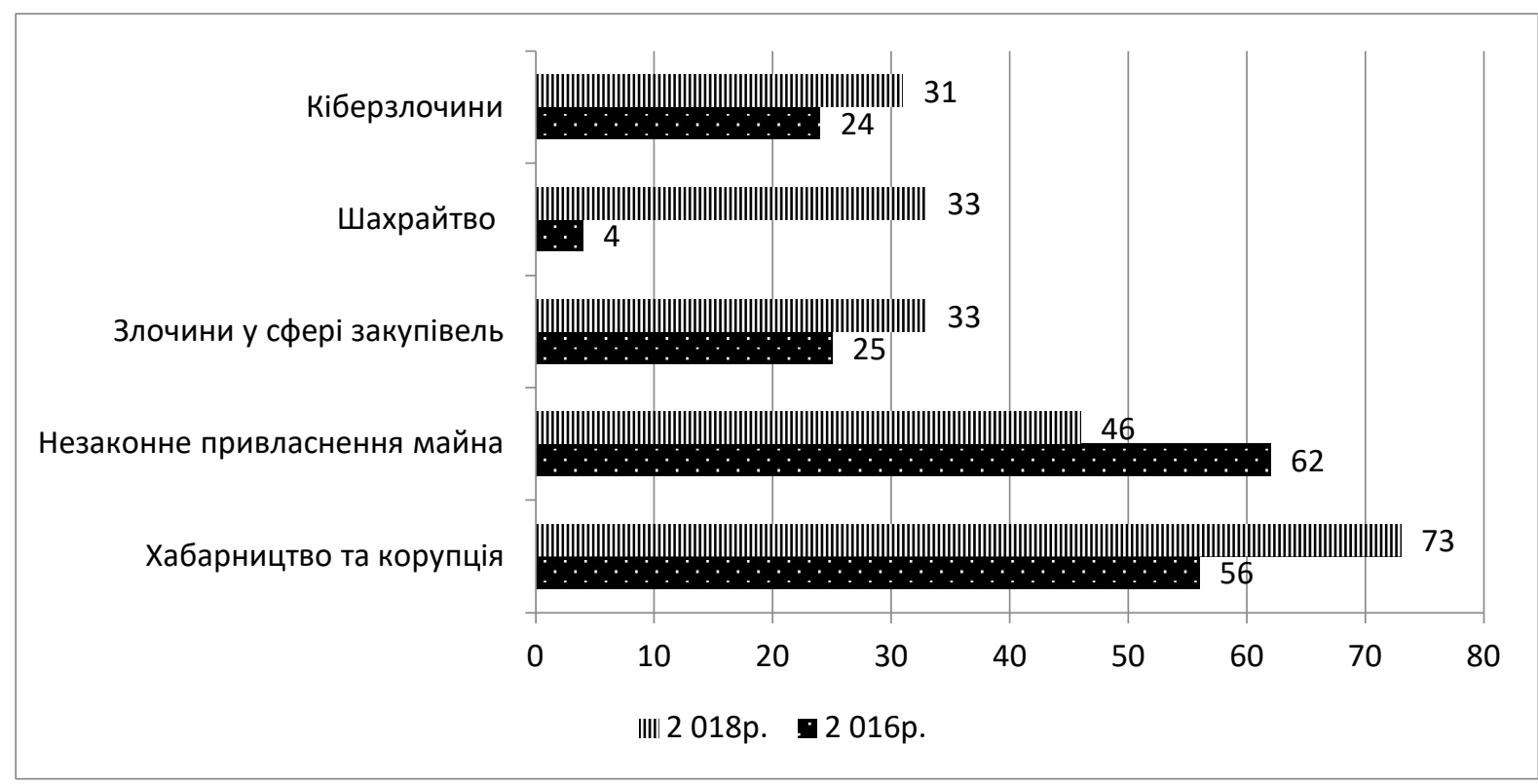

Рис. 9.5.4. Види економічних злочинів в Україні у 2016 р. та у 2018 р., \% Складено за [483]

Аналіз показує, що у 2018 р. в Україні значно знизився індекс сприйняття корупції - до 30 балів. Однак, як бачимо, вказані покращення не знайшли відображення в результатах опитування.

Існує таке твердження, що для того щоб протистояти злочинності ії потрібно вивчити, дослідити умови виникнення та чинники впливу, з чим ми абсолютно погоджуємося. Тому для профілактики та протидії економічним злочинам потрібно з’ясувати причини скоєння таких злочинів та сформувати «портрет» злочинця. Як показали результати опитування, у 2018 р. 36\% шахрайств були скоєні третіми особами [483], що відповідає загальносвітовій практиці. Так рівень шахрайств скоєний третьою стороною у світі становить $40 \%$. Водночас, частка шахрайств вчинених працівниками підприємств перевищила загальносвітовий рівень (52\%) і в Україні цей показник - 56\% [483]. Практика підтверджує, що здебільшого злочини проти своєї ж організації здійснює вище керівництво, частка підприємств, які вказали на це становить 55\%. Важливим $є$ те, що значення цього показника зросло вдвічі, порівняно із 2016 р. ( у 2016 р. - 27\%; у 2018 р. - 55\%). Основною причиною вчинення економічних злочинів $70 \%$ респондентів зазначили про наявність значно більших можливостей скоїти ці злочини, що на 28\% більше, аніж у 2016 р. 
3 метою розробки ефективних заходів боротьби із шахрайством доцільно виокремити основні фактори, що впливають на працівників. Існує три основних чинники, що призводять до здійснення шахрайства з боку працівників:

тиск в середині організації;

можливість вчинення шахрайства;

атмосфера виправдання дій працівників організації.

Для скоєння шахрайських дій працівниками необхідна сукупність всіх трьох чинників. Звідси, для запобігання шахрайству доцільно впливати на працівників та усувати можливі умови для вчинення злочинів. Це можливо шляхом формування атмосфери відкритості на всіх рівнях організації, запровадження ефективних механізмів внутрішньофірмового контролю, формування позитивної корпоративної культури та несприйняття співробітниками шахрайських дій.

Доцільно зазначити, що наслідки від шахрайства є не тільки фінансовими. Розголошення факту шахрайства (не важливо чи організація стала жертвою шахрайських дій, чи їх ініціатором) створює загрозу репутації організації, може підірвати діловий імідж суб'єкта господарювання. Проведене опитування показало, що від економічних злочинів та шахрайства потерпає репутація підприємства, на що вказало $50 \%$ опитаних респондентів. Водночас $42 \%$ опитаних зазначили, що від шахрайських дій постраждали їх відносини із бізнес-партнерами, а 38\% вказали на погіршення відносин із регуляторами (рис. 9.5.5).

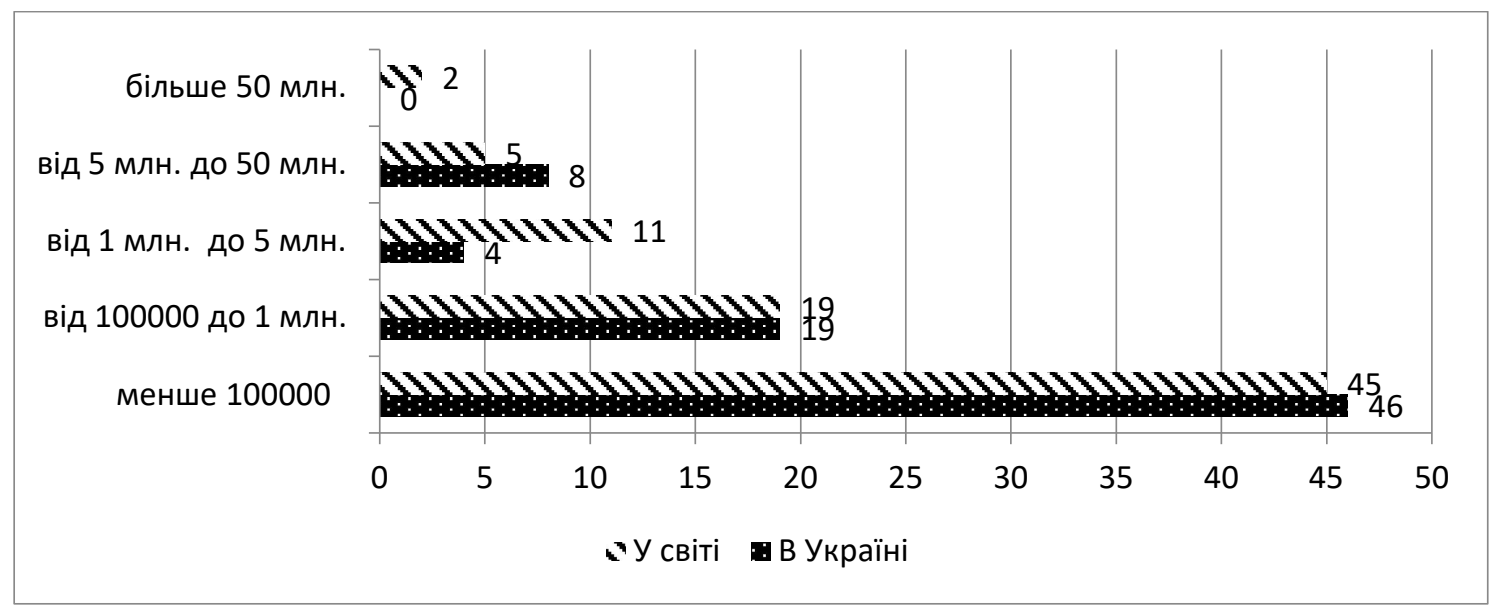

Рис. 9.5.5. Суми фінансових збитків підприємств від вчинених економічних злочинів в Україні і світі, дол. США* [483]

*Не враховані відповіді респондентів, які відповідали «Суму фінансових збитків неможливо оцінити» або «Важко відповісти» 
Вчинені економічні злочини позначаються і на психологічному кліматі в колективі, що проявляється у погіршені професійної етики та поведінки працівників, на що вказали 58\% опитаних.

Отже, банківська система - це одна з основних ланок фінансово-кредитної системи України. Саме тому вона є об'єктом, які приваблюють шахраїв та злочинців. Цей факт підриває авторитет банків, як фінансових посередників, що гарантують збереження та накопичення коштів клієнтів: населення, держави та суб'єктів господарювання. У сучасному світі способи шахрайств змінюються.

Впровадження банківських карт та використання сучасних комп'ютерних технологій у сфері банківських платежів $\epsilon$ характерною особливістю повсякденного життя. Досить швидко розвиваються безготівкові форми розрахунків. Безготівкові платежі мають низку переваг, а саме: сприяють прискоренню оборотності грошових коштів, скороченню кількості готівки, необхідної для обігу. Поширення безготівкових розрахунків призводить до зниження витрат обігу та збільшує прозорість розрахунків [484]. Отже, простота, доступність технологій, швидкість здійснення та дешевизна робить безготівкові розрахунки популярними серед населення та підприємств, а, отже, приваблюють шахраїв. На підтвердження цього факту наведемо такі дані: платіжні сервіси системи Exchange-Online у період з 01.01.2018 по 26.08.2018 зафіксували 12416 підозрілих операцій на загальну суму 3409000 гривень. В підозрілих операціях прийняло участь 7390 банківських карт 135 банків з 53 країн, в тому числі з 67 українських банків. Кошти шахраї намагалися вивести з рахунків клієнтів за допомогою мобільних пристроїв [482].

Ще одним важливим способом шахрайства $є$ використання соціальної інженерії, внаслідок чого зловмисники отримують дані платіжної картки та ідентифікацію іiі, як не дивно основною найбільш вразливою ланкою в цих маніпуляціях є сам клієнт. Шахраї використовують методи інтелектуального аналізу, психологічного впливу та інформаційних технологій, а далі справа швидкої техніки переведення коштів. 
Таким чином банківське шахрайство впливає не лише на банківські установи, уповільнюючи поширення безготівкових операцій, підриваючи довіру населення, але й для держави загалом, порушуючи стабільність банківської системи та ускладнюючи процес протидії шахрайству.

Впровадження банківських карт та використання сучасних комп'ютерних технологій у сфері банківських платежів $є$ характерною особливістю повсякденного життя. Досить швидко розвиваються безготівкові форми розрахунків. Безготівкові платежі мають низку переваг, а саме: сприяють прискоренню оборотності грошових коштів, скороченню кількості готівки, необхідної для обігу. Поширення безготівкових розрахунків призводить до зниження витрат обігу та збільшує прозорість розрахунків [484].

Звідси, простота, доступність технологій, швидкість здійснення та дешевизна робить безготівкові розрахунки популярними серед населення та підприємств, а, отже, приваблюють шахраїв. На підтвердження цього факту наведемо такі дані: платіжні сервіси системи Exchange-Online у період 3 01.01.2018 по 26.08.2018 зафіксували 12416 підозрілих операцій на загальну суму 3409000 гривень. В підозрілих операціях прийняло участь 7390 банківських карт 135 банків 353 країн, в тому числі з 67 українських банків. Кошти шахраї намагалися вивести з рахунків клієнтів за допомогою мобільних пристроїв [482].

Україна займає одне з перших місць серед поширення шахрайських дій у банківській сфері та потрапляє в п'ятірку країн, де банківські платіжні операції $\epsilon$ незахищеними. Зазначимо, що 19\% операцій, які підозрювалися в шахрайстві, виявились дійсно шахрайськими. Це показник перевищує обсяги шахрайств в інших країнах. Так, за допомогою кібершахрайств у 2018 р. 3 карток українців було знято 238955 гривень [482].

Банківські платіжні системи, які мають слабкий захист, можуть втрачати клієнтів, оскільки вони можуть стати об'єктами шахрайства. Залучення широких верств населення до здійснення безготівкових операцій та можливість отримання збитків серед них перетворює банківське шахрайство не тільки у проблему 
банків, але у соціальну проблему. Цю проблему потрібно вирішувати комплексно із залученням держави, населення, банків, інвесторів.

Найбільш поширеними видами банківських шахрайських операцій 3 картками є такі:

- скімінг - шахрайська операція, яка полягає у викраденні інформації 3 магнітної стрічки картки або ПІН-коду клієнта за допомогою спеціальних технічних пристроїв;

- трапінг - шахрайські дії, які полягають у встановленні пасток на шатер банкомату;

- пошкодження банкоматів;

- фішинг - шахрайські операції, що реалізуються із використанням мережі Інтернет;

- вішинг - шахрайство, що використовує мобільний зв'язок;

- вірусні та хакерські атаки, тощо.

На рисунку 9.5.6 наведені групи шахрайських операцій, здійснених у 2018 року та об’єднаних за однаковим способом здійснення, які представлені у відсотках.

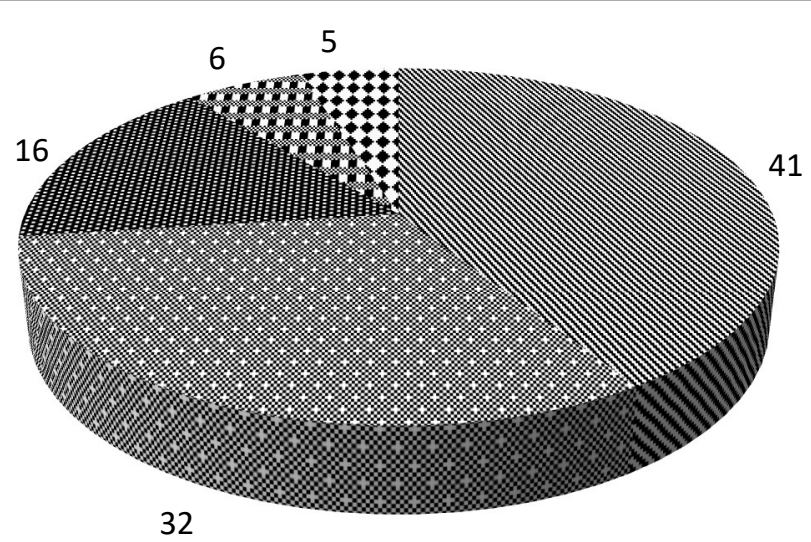

\$ Соціальна інженерія

Крадіжка коштів через банкомат

期 Шахрайські операції через інтернет

- Шахрайські операції через дистанційні мережі обслуговування

₹ Крадіжки через POS-термінали

Рис. 9.5.6. Банківські шахрайські операції за способом вчинення у 2018 р.,\% Складено на основі даних Української міжбанківської Асоціації членів платіжних систем [485] 
Найбільша частка банківських шахрайських операцій, які було здійснено за допомогою методів соціальної інженерії (41\%), реалізувались із використанням вішингу та фішингу. Сутність таких шахрайських дій полягає у виманюванні даних платіжних карток у клієнтів та отриманні доступу до рахунків та викрадені коштів. Жертвами соціальної інженерії, зазвичай, стають люди пенсійного віку (від 55 і старші) - 15\% та особи середнього віку (35-44) $13 \%$.

Як видно з рисунку 6, популярними способом крадіжок коштів у клієнтів банків крадіжки $є$ через банкомат (32\%) та через Інтернет (16\%). 3 огляду на популярність таких видів банківського шахрайства, банки повинні розробити способи захисту операцій.

Заради справедливості необхідно вказати, що банківське шахрайство, що реалізується $з$ використанням соціальної інженерії - це не лише проблема України, а глобальна проблема. Так, на кінець 2018 року шкоди від фішингових атак зазнали більше половини банків світу $-51,70 \%$.

Найбільше від фішингових атак постраждали банківські установи таких країн: Китай (20,87\%), Бразилія (19,16\%), Макао (11,94\%), Російська Федерація (11,29\%), Австралія (10,73\%), Аргентина (10,42\%), Нова Зеландія $(10,18 \%)$, Катар (9,87\%), Казахстан (9,61\%), Тайвань (9,27\%) [482].

Вішинг застосовували банківські шахраї у таких країнах: Росія $(1,2 \%)$, Узбекистан (0,40\%), Казахстан (0,36\%), Таджикистан (0,35\%), Туреччина (0,34\%), Молдова (0,31\%), Україна $(0,29 \%)$, Киргизстан $(0,27 \%)$, Білорусь $(0,26 \%)$ та Латвія $(0,23 \%)$ [482].

У 2018 році на 1 млн. грн. операцій за платіжними картками 92 грн. припадає на незаконні операції, тоді як у 2017 році - 77 грн. [486].

Щодо України, то у 2018 року збитки клієнтів банківських установ від соціальної інженерії склали 509,72 млн. грн. Такий рівень вдвічі перевищив збитки за 2017 рік та у 9 разів за 2016 рік.

Необхідно вказати, що у 2018 р. збільшилася середня сума шахрайської операції, які реалізовувалися з використанням методів соціальної інженерії. 
У 2018 р. вона склала 2543 грн., що в 1,8 разів перевищує даний показник у 2016 році (табл. 9.5.2).

Таблиця 9.5.2

Сума збитків отриманих від банківського шахрайств в Україні за 2016-2018 pp.

\begin{tabular}{|c|c|c|c|c|c|c|c|c|}
\hline \multirow{2}{*}{ Показники } & \multicolumn{2}{|c|}{2016 p. } & \multicolumn{2}{|c|}{2017 p. } & \multicolumn{2}{|c|}{2018 p. } & \multicolumn{2}{|c|}{$\begin{array}{l}\text { Абсолютне відхилення } \\
2018 \text { р. до } 2016 \text { р. }\end{array}$} \\
\hline & $\begin{array}{l}\text { Соціальна } \\
\text { інженерія }\end{array}$ & Інтернет & $\begin{array}{l}\text { Соціальна } \\
\text { інженерія }\end{array}$ & Інтернет & $\begin{array}{l}\text { Соціальна } \\
\text { інженерія }\end{array}$ & Інтернет & $\begin{array}{l}\text { Соціальна } \\
\text { інженерія }\end{array}$ & Інтернет \\
\hline $\begin{array}{l}\text { Середня } \\
\text { сума } \\
\text { збитку від } \\
\text { шахрайськ } \\
\text { ої операції, } \\
\text { грн. }\end{array}$ & 834 & 206 & 1403 & 345 & 2543 & 145 & 1709 & -61 \\
\hline $\begin{array}{l}\text { Загальна } \\
\text { сума } \\
\text { збитків від } \\
\text { шахрайськ } \\
\text { их } \\
\text { операцій, } \\
\text { млн. грн. }\end{array}$ & 51,74 & 32,62 & 275,45 & 63,68 & 509,72 & 159,91 & 457,98 & 127,29 \\
\hline
\end{tabular}

Складено за даними [482]

Найбільша кількість випадків банківського платіжного шахрайства в Україні здійснювались 3 використанням методів соціальної інженерії реалізуються в середовищі Card-Not-Present (операції без наявності картки та фізичної присутності користувача).

\section{Висновки.}

Тобто, найбільш популярними методами вчинення банківського шахрайства є використання соціальної інженерії. Це можна пояснити тим, що зловмисники отримують дані банківської картки та ідентифікаційні дані клієнта. Популярність соціальної інженерії пояснюється й тим, що даний спосіб шахрайства є досить простим у здійсненні. Не дивлячись на те, що банківські співробітники попереджають клієнтів не поширювати інформацію по банківській картці через телефон, проте шахраї мають досить багато способів 
впливу на жертву. Отже, найбільш слабким методом у платіжних системах є сам клієнт. Тут банківські установи $є$ безсилими. Тому для даного випадку шахрайства необхідно використовувати сукупність засобів, які грунтуються на методах інтелектуального аналізу та інформаційних технологій.

Банківське шахрайство має негативні наслідки для стабільності фінансової системи держави в цілому. Негативний вплив проявляється в уповільненні поширення безготівкових розрахунків, поширенні недовіри населення до банків, тонізації фінансових операцій. Необізнаність у механізмах вчинення банківського шахрайства ускладнюють процес його визначення та боротьби 3 ним. Виокремлення ознак шахрайства $€$ необхідним для розробки засобів $\mathrm{i}$ методів захисту від таких злочинів.

В результаті проведеного дослідження виявлено, що збитки від банківського шахрайства щорічно зростають. Клієнти банків самі банківські установи втрачають кошти завдяки різним шахрайським діям. Найбільш популярними методами здійснення банківського шахрайства $є$ соціальна інженерія, фішинг та вішинг. Для боротьби 3 такими видами банківського шахрайства доцільно розробити низку заходів, реалізація яких потребує застосування методів Data Mining та розвинутих інформаційних технологій. 